\title{
Screening of bacterial strains for developing effective pesticide- tolerant plant growth-promoting microbial consortia from rhizosphere soils of vegetable fields of eastern Uttar Pradesh, India
}

\author{
Jay Prakash Verma ${ }^{1} \cdot$ Durgesh Kumar Jaiswal $^{1} \cdot$ Punkaj Kumar Maurya $^{1}$ \\ ${ }^{1}$ Institute of Environment and Sustainable Development, Banaras Hindu Univeristy, Varanasi, Uttar Pradesh 221005, India
}

Received: 25 March 2016/Revised: 25 April 2016/Accepted: 17 May 2016/Published online: 25 May 2016

(c) Joint Center on Global Change and Earth System Science of the University of Maryland and Beijing Normal University and Springer-Verlag Berlin Heidelberg 2016

\begin{abstract}
The current study was intended to isolate and characterize the plant growth-promoting properties and pesticide (chlorpyripfos) tolerance ability of microbial strains for sustainable vegetable productions. Plant growthpromoting microorganism is a group of microbial consortia to improve crop growth and yield by various direct mechanisms, e.g. nitrogen fixation, phosphate solubilization, production of plant growth hormones, ammonia and siderophore, and indirect mechanisms, e.g. production of antibiotic, hydrogen cyanide to help as biocontrolling agent. Totally, 50 microbes were isolated from soils of vegetable field. Out of 50,14 strains were selected on the basis of morphological, growth biochemically characters (e.g. gram staining, amylase, cellulase, catalase and citrate test) and plant growth-promoting properties. All strains have ability of ammonia production. Out of 14 strains, IESDV2, IESDV3, IESDV4, IESDV11, IESDV12 and IESD28 were found significant increase in production of IAA, ammonia and phosphate solubilization than others. Strains IESDV3 and IESDV11 showed tolerant at $6 \mu \mathrm{l} / \mathrm{ml}$ concentration of chlorpyrifos which is three-time increase concentration of recommended dose $(2 \mu \mathrm{l} / \mathrm{ml})$. Others strains IESDV12, IESDV13 and IESDV28 were also showed resistance or tolerance at different concentrations of pesticide 2, 4, 6 and $20 \mu \mathrm{l} / \mathrm{ml}$. These strains also showed plant growth-promoting rhizobacteria activities. Therefore, the main result of this study is to screen and identify that three strains (IESDV3, IESDV11, IESDV12 and IESDV28) can be used as effective pesticide-tolerant plant growth-promoting microbial
\end{abstract}

Jay Prakash Verma

verma_bhu@yahoo.co.in; jpv.iesd@gmail.com consortia for vegetable production under sustainable agriculture at eastern Uttar Pradesh.

Keywords Plant growth-promoting microorganism (PGPM) - Pesticide · Microbial consortia · IAA · Phosphate solubilization - Sustainable agriculture

\section{Introduction}

In the agricultural sector, the vegetables are the most vital part of Indian agriculture and nutritional security due to their short life cycle, high yield, nutritional richness, economic viability and also provide the employment opportunity to rural non-farmer and farmer sector.

India has diverse climatic conditions with different weather phenomena, which helps in growing a wide range of vegetable and fruit production. Therefore, India has putted on the second rank in vegetable and fruit production in worldwide. Vegetable is very important foods for human being to fulfill the daily requirement of essential minerals, vitamins, carbohydrate, proteins and antioxidants for healthy societies. Currently, ensuring demand of vegetable production for feeding of increasing population in worldwide is due to application of increasing chemical input such as synthetic fertilizer and pesticide. The pesticides are used for controlling pest and insect in vegetables because these pests and insect cause loss of productivities of vegetables. The extensive usage of chemical fertilizers and pesticides caused a number of deaths and illness in humans (Verma et al. 2014). These pesticides adsorb in the soils to persist a long time in the environment due to more half-life. Moreover, the improper 
farm management practices and improper application of agrochemicals and pesticides have also caused degradation of soil fertility and health (Setboonsarng and Gilman 2006). The nutritional quality of food gains and vegetables are decreasing due to the loss of soil properties. Nutrient deficiency and heavy metal-related disease are increasing in human and animals day by day.

However, sustainable agricultural practices must be essential for providing better food and fibre for healthy nation. Only effective microbes are an alternative to chemical fertilizers and pesticides for enhancing vegetable production under sustainable agriculture. These microbes also have ability to survive under pesticide and adverse environmental condition because indigenous microbes can change their physiological and genetic character according to environmental condition. Bioremediation and microbial degradation are being used for the destruction of chemicals in soil and ground water. The bacteria belonging to genera, Pseudomonas, Arthobacter, Ralstonia and Rhodococcus (Park et al. 2003); Bacillus, Planococcus and Acetobacter (Shakoori et al. 2000) and Alcaligenes (Padmanabhan et al. 2003) were isolated from different places of the world with incredible property to degrade xenobiotic contaminants. These pesticide pollutants are removed from the soil by indigenous microorganisms, including bacteria for their extraordinary characteristic to use a wide range of xenobiotics as sole energy and carbon source (Siddique et al. 2003).

In other words, indigenous microorganism is also known as plant growth-promoting microorganism (PGPM) which lives in microbial cells of bacteria, actinomycetes and fungi. PGPM inoculants presently commercialized as innovative and efficient solution for plant growth enhancement through direct and indirect mechanisms. Indirect mechanism includes antibiotic protection for controlling pathogenic microbes, reduction in iron, synthesis of chitinase enzyme and competition with disadvantageous microbes from site of plant root (Vessey 2003). Direct mechanism includes nitrogen fixation, nutrient solubilization as phosphate, siderophores for iron, production of plant hormones such as auxins, cytokinin and gibberellin and decreases the plant ethylene level (Glick 1995). PGPM (Pseudomonas, Azospirillum, Azotobacter, Klebsiella, Enterobacter, Alcaligenes, Arthrobacter, Burkholderia, Bacillus, Serratia, Aspergillus, Penicillium and Trichoderma) was reported to increase plant growth (Glick 1995; Verma et al. 2010, 2012, 2013, 2014). Criollo et al. (2011) reported that three liquid biofertilizers (Saccharomyces sp., Lactobacillus sp. and Bacillus sp.) had recorded the enhancement of head diameter and yield of Lactuca sativa L. and cabbage (Brassica oleracea L. var. capitata) as compared to control. Paul and Dubey (2014) reported that Rhizobium sp., Pseudomonas sp., Yeast sp., Bacillus sp. and Azotobactor sp. were isolated and characterized as effective biofertilizer which enhance the production of Capsicum annuum, Solanumbetaceum, Solanummelongena. Gupta and Samnotra (2004) reported a $25 \%$ reduction in nitrogen application when Azotobacter and Azospirillum were used as the organic source of nitrogen in cabbage. Yadav et al. (2004) reported that the applications of biofertilizers (Azospirillum) in onion improve the productivity. Azospirillum inoculation gave a significantly higher bulb yield of onion over control.

Presently, some PGPM is available only single or dual microbial consortium in the market, which is not effective for all the vegetables and they are not having the ability to degrade and tolerance against pesticides. They have brought from other agro-climatic region, which is not survived and sustained in the soils of other regions. This is a big problem in PGPM as biofertilizers which are currently available in the markets for farmer's application. In order to overcome these problems, the need of alternative practices like the effective pesticide degrading plant growth promoting microbial consortia are required for improving plant growth of vegetables and degrade or minimize the pesticides in soils. These consortia can degrade and utilize the pesticides as a sole source of carbon and enhance plant growth because of having plant growth-promoting properties. These consortia can easily grow and help in degradation of pesticides in soils of vegetable fields. Therefore, the aim of the present study is to screen bacterial strains for the development of efficient indigenous pesticide-tolerant plant growth-promoting microbial consortia from rhizosphere soils of eastern Uttar Pradesh.

\section{Materials and methods}

\subsection{Collection of soil samples}

The rhizosphere and non-rhizosphere soil samples were collected from vegetable field of okra, brinjal, tomato and chilli from Indian Institute of Vegetable Research (IIVR), Varanasi, Jaunpur and Mirzapur, eastern Uttar Pradesh, India, during June 2015. Totally, fifty samples were collected, and finally, two samples were mixed with similar plots to make total of 25 composite soil samples. The vegetable fields had continuously been applied on average 4 times pesticide (Carbendazim-1.5g/L and Chlorpyrifos$2 \mathrm{ml} / \mathrm{L}$ ) application in vegetable fields for insect prevention, where samples were collected. The soil samples had taken up to depth of $15-20 \mathrm{~cm}$ by using the auger in sterilized plastic polythene. The collected samples were separated into two sterilized polythene: one for microbiological work and others for soil analysis stored at $4{ }^{\circ} \mathrm{C}$ and room temperature, respectively. Out of 25 samples, only five samples were selected for chemical analysis and isolation of 
microbial strains because these five samples taken from those fields, where more pesticide used for vegetable production for a long time. The air-dried and 2-mm soil particle were prepared for chemical analysis of soils and also stored these samples in sealed plastic bags at room temperature.

\subsection{Isolation of bacterial strains}

The serial dilution and plating techniques were performed for isolation of soil bacteria. The serial dilution was prepared by adding $1 \mathrm{~g}$ of soil sample containing $9 \mathrm{ml}$ sterile $(0.85 \%$ saline) water as first dilution $10^{-1}$. The serial dilutions prepared up to $10^{-6}$ in test tube by adding $0.1 \mathrm{ml}$ aliquots from each dilution. A volume of $0.01 \mathrm{ml}$ of aliquot was taken from each dilution and plated on Petri plate containing respective media such as nutrient agar (peptone 5.0, yeast extract 1.5 $\mathrm{g} / \mathrm{l}$, beef extract $1.5 \mathrm{~g} / \mathrm{l}, \mathrm{NaCl} 0.5 \mathrm{~g} / \mathrm{l}$, agar $15.0 \mathrm{~g} / \mathrm{l}, \mathrm{pH}$ 7.0.), Kenknight and Munaiers agar (dextrose $1.0 \mathrm{~g} / 1, \mathrm{KH}_{2} \mathrm{PO}_{4}$ $0.1 \mathrm{~g} / 1, \mathrm{NaNO}_{3} 0.1 \mathrm{~g} / \mathrm{l}, \mathrm{KCl} 0.1 \mathrm{~g} / 1, \mathrm{MgSO}_{4} 0.1 \mathrm{~g} / \mathrm{l}$, agar $15.0 \mathrm{~g} / \mathrm{l}$ ), Pikovskaya agar (glucose $10.0 \mathrm{~g} / \mathrm{l}$, yeast extract $0.5 \mathrm{~g} / \mathrm{l},\left(\mathrm{NH}_{4}\right)_{2} \mathrm{SO}_{4} 0.5 \mathrm{~g} / \mathrm{l}, \mathrm{KCl} 0.2 \mathrm{~g} / \mathrm{l}, \mathrm{MgSO}_{4} 0.1 \mathrm{~g} / \mathrm{l}$, $\mathrm{FeSO}_{4} \cdot 7 \mathrm{H}_{2} \mathrm{O}$ trace, $\mathrm{MnSO}_{4}$ trace, $\mathrm{Ca}_{3}\left(\mathrm{PO}_{4}\right)_{2} 5.0 \mathrm{~g} / \mathrm{l}$, agar $15.0 \mathrm{~g} / \mathrm{l}, \mathrm{pH}$ 7.0) and King's $\mathrm{B}$ base (protease peptone $10.0 \mathrm{~g} / \mathrm{l}$, glycerol $10.0 \mathrm{ml}, \mathrm{K}_{2} \mathrm{HPO}_{4} 1.5 \mathrm{~g} / \mathrm{l}, \mathrm{MgSO}_{4} 1.5 \mathrm{~g} / \mathrm{l}$, Agar $15.0 \mathrm{~g} / \mathrm{l}, \mathrm{pH}$ 7.2). After plating, the plates were sealed and incubated for $2-5$ days at $30^{\circ} \mathrm{C}$ temperature. The counting of colonies on media plates was done. The different colonies were found on media plates which was isolated and subcultured for further analysis. The halo zone was observed on Pikovskaya agar media to show the properties of phosphate solubilization. All bacterial isolate were subcultured on their respective medium by the streaking method to get pure colonies and stored at $4{ }^{\circ} \mathrm{C}$ in the refrigerator for further use. We have isolated 50 microbial strains from rhizosphere soils. Sterilization process was done by autoclave at $15 \mathrm{lbs}$ pressure and $121{ }^{\circ} \mathrm{C}$ temperature for $15 \mathrm{~min}$.

\subsection{Chemical properties of field soils}

The chemical properties of collecting soils were analysed as neutral in reaction (pH) (Chopra and Kanwar 1982), electronic conductivity (Sparks et al. 1996) and organic carbon (Walkley and Black 1934). The total bacteria, fungi and actinomycetes were observed in (colony farming unit) CFU/g soil (Aneja 2003).

\subsection{Morphological and biochemical properties}

Out of 50, 14 microbial strains were selected according to morphological character such as colonies margin, shape, colour and gram staining (Aneja 2003; Kloepper and Beauchamp 1992). Fourteen bacterial strains were also selected for various biochemical properties, e.g. amylase, catalase and cellulase test. Bacterial isolates were employed for amylolytic activity by starch hydrolysis test on starch agar plate $(20 \mathrm{~g}$ starch, $5.0 \mathrm{~g}$ peptone, $3 \mathrm{~g}$ beef extract and $15 \mathrm{~g}$ agar in $1000 \mathrm{ml} \mathrm{pH} \mathrm{7.0).} \mathrm{The} \mathrm{cellulase}$ production test was done with the help of Congo red agar media $\left(0.5 \mathrm{~g} \mathrm{KH}_{2} \mathrm{PO}_{4}, 0.25 \mathrm{~g} \mathrm{MgSO}_{4}, 2 \mathrm{~g}\right.$ cellulose, $15 \mathrm{~g}$ agar, $0.2 \mathrm{~g}$ Cong red and $2 \mathrm{~g}$ gelatine; $1000 \mathrm{ml}$ water at $\mathrm{pH}$ 6.8-7.2). The catalase test is performed by placing a few drops of $3 \% \mathrm{H}_{2} \mathrm{O}_{2}$ on $24 \mathrm{~h}$ of growing culture stains on microscopic slide. The citrate test is performed by inoculating the microbial strains on Simmon's citrate agar $(1.0 \mathrm{~g}$ ammonium dihydrogen phosphate, $1.0 \mathrm{~g}$ dipotassium phosphate, $2.0 \mathrm{~g} \mathrm{NaCl}, 0.2 \mathrm{~g}$ magnesium sulphate, $15 \mathrm{~g}$ agar and $0.08 \mathrm{~g}$ bromothymol in $1000 \mathrm{ml}$ water) containing $7 \mathrm{ml}$ media in each test tube though streaking methods.

\subsection{Effect of chlorpyrifos pesticide on growth of microbes and their interaction}

We have selected this pesticide on the basis of farmer's discussion, and they were applied insecticide as chlorpyrifos pesticide in vegetable fields continuously. Disc diffusion method was used for the growth of microbes with pesticide. The effects of different concentrations of pesticide on microbial growth were observed on media plate by using the filter paper disc technique. This technique also used to test antibiotics resistance of microbes (Bauer et al. 1966) and presently used to test the effect of pesticide on microbial growth (Mallik and Tesfai 1983; Martensson 1992). Chlorpyrifos insecticide commercial name Messban $20 \% \mathrm{EC}$ was obtained from the market. The recommended dose of chlorpyrifos is $2 \mathrm{ml} / \mathrm{l}$ of water. The recommended dose of chlorpyrifos was diluted to 2, 4, 6 and $20 \mu 1 / \mathrm{ml}$ using the same solvent (water). The sterile filter paper disc was used for pesticide test. The sterilized discs were dipped in different concentrations of pesticides and put on respective microbial inoculated plate of nutrient agar under laminar air flow. Control disc was dipped in sterile distilled water and put on the respective media with inoculated strains. Pesticide discs were put on the nutrient agar plate which is uniformly spread with pure cultures of different microbial strains. The plates were then incubated at $30{ }^{\circ} \mathrm{C}$ for $48 \mathrm{~h}$. Thus, each plate contained four discs, which correspond to the concentrations (control, 2, 4, 6 and $20 \mu \mathrm{l} /$ $\mathrm{ml})$ prepared for pesticide. After $48 \mathrm{~h}$, the zones of inhibition around the discs were observed.

\subsection{Evaluation of plant growth-promoting activities in vitro condition}

Plant growth-promoting properties (quantitative estimation of phosphate solubilization, indole-3-acetic acid (IAA) and 
ammonia production) of isolated strains were evaluated by using following standard methods Brick et al. (1991). $\mathrm{NH}_{3}$ production was tested by the method of Cappuccino and Sherman (1992). The quantitative of phosphate solubilization in broth medium was extracted by the methods of ammonium bicarbonate diethylene triamine penta-acetic acid (AB-DTPA) (Soltanpour and Workman 1979). Also, the soluble phosphorus was determined by the modified methods of ascorbic acid (Watanabe and Olsen 1965; Yadav et al. 2011).

\subsection{Statistical analysis}

The experimental set-up was prepared with 19 treatments and three replications. The data were analysed by using SPSS software (version 16.0). Duncan post hoc multiple comparison tests were performed through analysis of variance (ANOVA). The values of $P \leq 0.05$ were considered as statistically significant.

\section{Results and discussions}

\subsection{Chemical properties of collected soils}

The $\mathrm{pH}$ of collecting soil samples ranged from 6.85 to 8.04. The $\mathrm{pH}$ of samples showed varied value due to pesticide and chemical contamination. The $\mathrm{pH}$ value is a very important factor for the growth of microbial populations and their activities. According to $\mathrm{pH}$, the microbial strains can characterize as acid- and alkali-tolerant strains. Similarly, Sharma et al. (2013) reported that in soils of IIVR research farm, the $\mathrm{pH}$ ranged from 6.661 to 7.82 with mean of 7.34. Soil pH is an important factor in nutrients availability for the plant growth and development. Some of the vegetable crops need slightly acidic to neutral soil environment for the best growth (Sharma et al. 2011). The electrical conductivity (EC) ranged from 0.23 to $0.63 \mathrm{mS} /$ $\mathrm{cm}$. The EC values are also important for the growth of microbial population, which helps in nutrient mobilization. Also, it shows the presence of cations and anions in a soil sample. EC of the IIVR farm of soil is ranged from 0.09 to $0.76 \mathrm{dS} / \mathrm{m}$ with a mean value of $0.28 \mathrm{dS} / \mathrm{m}$ (Sharma et al. 2013). The higher EC value indicates the presence of more soluble salts in the soil environment. The organic carbon (OC) of soils was recorded and ranged from 0.53 to $0.85 \%$. The higher OC was found to be $0.85,0.80,0.77$, 0.68 and $0.53 \%$ in soil samples of IIVR1, IIVR2, IIVR3, JDV4 and MDV5, respectively (Table 1). The OC is used as an energy source for microbes for their growth and development. According to Sharma et al. (2013), the soil organic carbon of IIVR was found in the range of 0.39 to
0.84 with an average of $0.57 \%$. Soil organic carbon can directly link with soil organic matter that can be used an index of nitrogen availability. The chemical properties of collecting soils showed varied range for $\mathrm{pH}, \mathrm{EC}$ and $\mathrm{OC}$ because of pesticides contamination in vegetable fields (Aktar et al. 2009; Armanpour and Bing 2015).

\subsection{Isolation of microbes and their morphological characterization}

The average microbial populations were: bacterial $\left(60 \times 10^{5}\right.$, $72 \times 10^{5}, 95 \times 10^{5}, 107 \times 10^{5}$ and $\left.68 \times 10^{5} \mathrm{cfu} / \mathrm{g} / \mathrm{soil}\right)$; fungi $\left(109 \times 10^{4}, 272 \times 10^{4}, 211 \times 10^{4}, 129 \times 10^{4}\right.$ and $\left.104 \times 10^{4} \mathrm{cfu} / \mathrm{g} / \mathrm{soil}\right) ;$ and actinomycetes $\left(60 \times 10^{4}\right.$, $120 \times 10^{4}, 245 \times 10^{4}, 112 \times 10^{4}$ and $\left.85 \times 10^{4} \mathrm{cfu} / \mathrm{g} / \mathrm{soil}\right)$ in soil, respectively, after 48-h incubation (Table 2). According to results of microbial populations, fungal populations were recorded more as compared to actinomycetes and bacteria. Therefore, insecticides as pesticide application in vegetable fields caused to decrease the population of bacteria and actinomycetes as compared to fungi. Fungi are more resistance to insecticide (Farenhorst et al. 2009; Ambethgar 2009). At the time of colony counting on media plates, different and similar type colonies were found. Total numbers of 50 microbial colonies were isolated on the basis of different morphological characters. Out of 50 strains, totally 14 different bacterial strains were screened and characterized on the basis of morphological, visual observation, biochemical and plant growth-promoting activities (Aneja 2003).

The bacterial cell shape was found generally rod, coccus or circular rod, streptococci. The cell morphological properties have been found as circular (IESDV1, IESDV2, IESDV3, IESDV4, IESDV12, IESDV13, IESDV14, IESDV14, IESDV23, IESDV26 and IESDV27) and irregular (IESDV5, IESDV10, IESDV11 and IESDR28; (Table 3). Isolated strains showed various types of colony margin such as entire (IESDV1, IESDV3, IESDV4, IESDV12, IESDV13, IESDV14, IESDV23, IESDV26 and IESDV 27), undulate (IESDV2 and IESDV7), curled (IESDV5) and lobate (IESDV10 and IESDV11). The elevation like flat and convex has been also shown in isolated strains. On the basis of gram staining, bacterial strains were characterized as gram positive (IESDV1, IESDV2, IESDV3, IESDV10, IESDV11, IESDV12, IESDV13, IESDV14, IESDV23, IESDV27 and IESDV28) and gram negative (IESDV4, IESDV5 and IESD26; Table 3). We have found various types of morphological and colours of isolated bacterial strains. Similarly, Hafeez et al. (2006) reported that the visual observation and morphological character are varied in each microbial strain which has isolated from environmental samples. 
Table 1 Chemical property of collected soils

\begin{tabular}{llll}
\hline Sample no. & $\mathrm{pH}$ & Electrical conductivity $(\mathrm{mS} / \mathrm{cm})$ & Organic carbon $(\%)$ \\
\hline IIVR1 & 7.82 & 0.63 & 0.85 \\
IIVR2 & 8.04 & 0.23 & 0.80 \\
IIVR3 & 8.02 & 0.30 & 0.77 \\
JDV4 & 7.76 & 0.45 & 0.68 \\
MDV5 & 6.85 & 0.28 & 0.53 \\
\hline
\end{tabular}

Table 2 Microbial population in collected soil samples from IIVR, Jaunpur and Mirzapur district

\begin{tabular}{lllr}
\hline Sample no. & \multicolumn{2}{l}{ Microbial population } & \multicolumn{1}{c}{$\begin{array}{l}\text { Actinomycetes } \\
\left(\times 10^{4} \text { CFU/g soil }\right)\end{array}$} \\
\cline { 2 - 4 } & $\begin{array}{l}\text { Bacteria } \\
\left(\times 10^{5} \text { CFU/g soil }\right)\end{array}$ & $\begin{array}{l}\text { Fungi } \\
\left(\times 10^{4} \text { CFU/g soil }\right)\end{array}$ & 60 \\
\hline IIVR1 & 60 & 109 & 120 \\
IIVR2 & 72 & 272 & 245 \\
IIVR3 & 95 & 211 & 112 \\
JDV4 & 107 & 129 & 85 \\
MDV5 & 68 & 104 & 85 \\
\hline
\end{tabular}

CFU colony forming unit

Table 3 Morphological characteristics of isolated microbial strains

\begin{tabular}{|c|c|c|c|c|c|}
\hline \multirow[t]{2}{*}{ Strains } & \multicolumn{3}{|c|}{ Cell morphology } & \multicolumn{2}{|c|}{ Colony morphology } \\
\hline & Staining & Shape & Form & Elevation & Margin \\
\hline IESDV1 & Positive & Coccus & Circular & Flat & Entire \\
\hline IESDV2 & Positive & Rod and circular & Circular & Flat & Undulate \\
\hline IESDV3 & Positive & Coccus & Circular & Flat & Entire \\
\hline IESDV4 & Negative & Streptococci & Circular & Flat & Entire \\
\hline IESDV5 & Negative & Coccus & Irregular & Flat & Curled \\
\hline IESDV10 & Positive & Coccobacillus & Irregular & Flat & Lobate \\
\hline IESDV11 & Positive & Coccobacillus & Irregular & Flat & Lobate \\
\hline IESDV12 & Positive & Rod and circular & Circular & Flat & Entire \\
\hline IESDV13 & Positive & Coccus & Circular & Flat & Entire \\
\hline IESDV14 & Positive & Bacillus & Circular & Flat & Entire \\
\hline IESDV23 & Positive & Coccobacillus & Circular & Flat & Entire \\
\hline IESDV26 & Negative & Streptococci & Circular & Convex & Entire \\
\hline IESDV27 & Positive & Diplococci & Circular & Convex & Entire \\
\hline IESDV28 & Positive & Rod and circular & Irregular & Flat & Undulate \\
\hline
\end{tabular}

\subsection{Biochemical characterization of isolated strains}

A general biochemical feature of bacterial isolates is illustrated in Table 4. The bacterial strains were characterized by their biochemical properties (e.g. amylase, cellulase production, catalase and citrate test) using standard methods (Cappuccino and Sherman 1992; Aneja 2003). Some microbial strains showed positive and negative test for the production of amylase, cellulose, catalase and citrate (Fig. 1a-d; Table 4). The all bacterial strains showed positive test for amylase and cellulase production.
Amylase is starch-degrading enzymes which are widely distributed in microbes, plants and animals kingdoms. They degrade starch and related polymers to form products which are characteristics of individual amylolytic enzymes. Strains IESDV5, IESDV10, IESDV13, IESDV14, IESDV23, IESDV26, IESDV27 and IESDV28 showed higher zone of solubilization on cellulose Congo red agar media as compared to strains IESDV1, IESD2, IESD3, IESD4, IESD11 and IESD12. Dunne et al. (1998) reported that the chitinase, protease, gluconase or cellulase enzymes have ability to degrade the structural matrix of fungal cell 
Table 4 Biochemical characterization of isolated microbial isolated strains

\begin{tabular}{|c|c|c|c|c|}
\hline Strains & Amylase test & Cellulase test & Catalase test & Citrate test \\
\hline IESDV1 & +++ & + & + & + \\
\hline IESDV2 & ++ & ++ & + & + \\
\hline IESDV3 & ++ & ++ & - & + \\
\hline IESDV4 & + & ++ & - & - \\
\hline IESDV5 & +++ & +++ & + & - \\
\hline IESDV10 & +++ & +++ & - & + \\
\hline IESDV11 & ++ & ++ & - & + \\
\hline IESDV12 & ++ & ++ & ++ & + \\
\hline IESDV13 & ++ & +++ & + & - \\
\hline IESDV14 & ++ & +++ & + & - \\
\hline IESDV23 & ++ & +++ & - & + \\
\hline IESDV26 & ++ & +++ & - & ++ \\
\hline IESDV27 & ++ & +++ & + & ++ \\
\hline IESDV28 & +++ & +++ & + & ++ \\
\hline
\end{tabular}

"+" sign mean positive test, "-" sign mean negative test

wall, and also, this was a potential property of PGPR. All isolated stains gave the positive test for citrate utilization except strains IESD4, IESDV10, IESDV13 and IESDV14. The citrate utilization test has been performed to distinguish between members of the Enterobacteriaceae family based on their metabolic by-products. The positive citrateproducing microbes have potential ability to utilize sodium citrate as its only carbon source and inorganic $\mathrm{NH}_{4} \mathrm{H}_{2} \mathrm{PO}_{4}$ is used as a nitrogen source. The catalase test was also given positive in many bacterial strains except strains IESD3, IESD4, IESD10, IESD11, IESD23 and IESD26 (Table 4). The enzyme catalase present in some microorganisms breaks down hydrogen peroxide to water and oxygen and helps them in their survival (McCord et al. 1971; Aneja 2003).

\subsection{Effect of chlorpyrifos pesticide on growth inhibition of microbes}

The chlorpyrifos pesticide is a commercial available group of organophosphate pesticide which is the broad range of insecticide used in agricultural production. We have tested the effect of this pesticide on microbial growth on nutrient agar media by the methods of disc diffusion. The growth inhibition test was performed by different concentrations of pesticide 2, 4, 6 and $20 \mu \mathrm{l} / \mathrm{ml}$. The bacterial strains IESDV5, IESDV10, IESDV12, IESDV13 and IESDV28 were showed no inhibition zone against this pesticide that means these strains are more tolerant (Fig. 2; Table 5). In 4, 6 and $20 \mu 1 / \mathrm{ml}$ concentrations, only two strains IESDV4 and IESDV27 showed growth inhibition zone that means very less tolerant (Fig. 2). Two strains IESDV2, IESD4, IESDV14 and IESD27 were recorded growth inhibition at 6 and $20 \mu \mathrm{l} / \mathrm{ml}$ concentrations. At $20 \mu \mathrm{l} / \mathrm{ml}$ concentration of chlorpyrifos, all strains have ability to show growth inhibition zone on a media plate except the strains IESDV5, IESD6, IESDV12, IESDV13 and IESDV28 (Table 5). On the basis of this growth inhibition test, bacterial strains were divided into three categories: more, moderate and very less tolerant. On the basis of this, more tolerant strain may be have some ability to degrade or resistance against this organophosphate, but some strains have shown growth inhibition zone at 2 or 4 or $6 \mu \mathrm{l} / \mathrm{ml}$, and these types of strains may not have the ability to degrade the pesticides. These strains have no inhibition zone and grow well on a media plate that strains may be degraded the pesticide and used as a sole source of carbon for their growth and development (Verma et al. 2014; Hamada et al. 2015; Jadhav and David 2016).

\subsection{Plant growth-promoting activities of isolated strains}

All microbial strains have shown an ability of plant growth-promoting properties such as production of IAA, phosphate solubilization and ammonia. All bacterial strains showed significant increase in IAA production as compared to strain IESDV23 at 150 and $300 \mu \mathrm{g} / \mathrm{ml}$ tryptophan concentrations as the precursor in broth media, respectively, after 2-day incubation. The IAA production was recorded and ranged from 13.03 to $30.58 \mu \mathrm{g} / \mathrm{ml}$ and from 13.74 to $34.91 \mu \mathrm{g} / \mathrm{ml}$ at 150 and $300 \mu \mathrm{g} / \mathrm{ml}$ tryptophan concentrations, respectively. Bacterial strains IESDV12 (30.58 and $34.91 \mu \mathrm{g} / \mathrm{ml})$, IESDV11 (18.71 and $32.08 \mu \mathrm{g} / \mathrm{ml})$, IESDV26 (30.10 and $31.28 \mu \mathrm{g} / \mathrm{ml})$ and IESDV27 (24.80 and $32.53 \mu \mathrm{g} / \mathrm{ml}$ ) showed more statistically significant IAA production in broth culture at 150 and $300 \mu \mathrm{g} / \mathrm{ml}$ tryptophan concentrations, respectively. In support of present results, different scientists found that the IAA production by various microbial strains has ability to show the IAA activities varied within species and/or strains of the same species (Abbasi et al. 2011; Quadt-Hallmann and Kloepper 1996; Verma et al. 2010, 2013). Others strains, IESDV2 (22.56 and $23.19 \mu \mathrm{g} / \mathrm{ml})$, IESDV3 (23.57 and $26.61 \mu \mathrm{g} /$ $\mathrm{ml})$, IESDV4 (20.03 and $25.28 \mu \mathrm{g} / \mathrm{ml})$, IESDV5 (21.02 and $22.54 \mu \mathrm{g} / \mathrm{ml})$, IESDV10 (25.61 and $22.30 \mu \mathrm{g} / \mathrm{ml}$ ) and IESDV28 $(20.27$ and $23.68 \mu \mathrm{g} / \mathrm{ml})$, also found more significant enhancement in IAA production than other strains at 150 and $300 \mu \mathrm{g} / \mathrm{ml}$ tryptophan concentrations, respectively (Table 6). Verma et al. (2010) have reported that tryptophan is a precursor of IAA biosynthesis; for example, $P$. fluorescens found significant increase in IAA production in the presence of different concentrations of tryptophan. All strains have the ability to synthesize IAA production in 


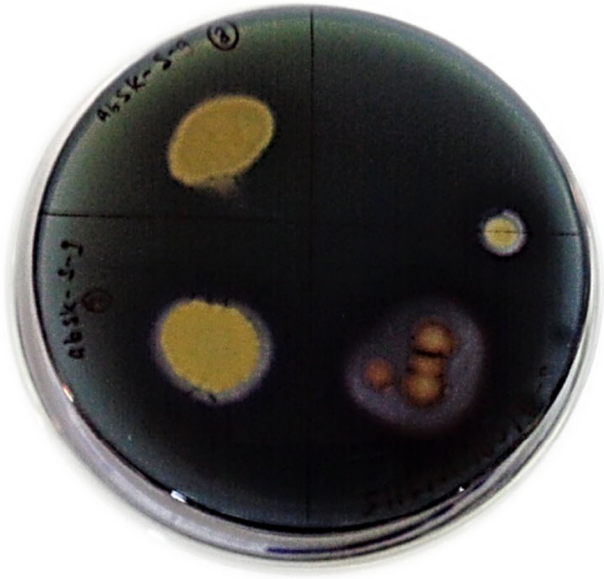

A Amylase test

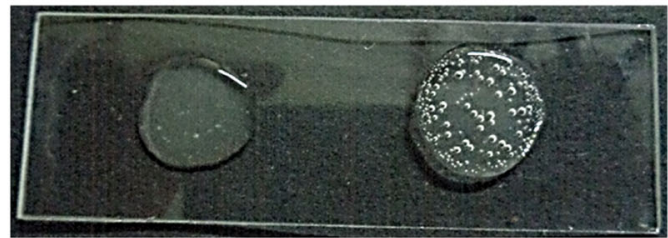

Control

C Catalase test

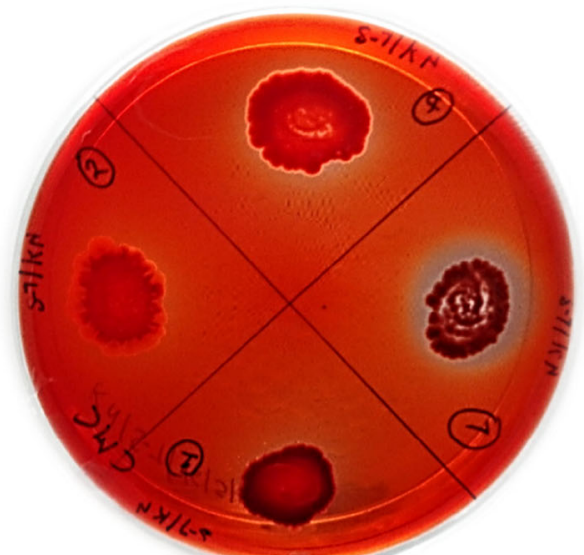

B CMC test

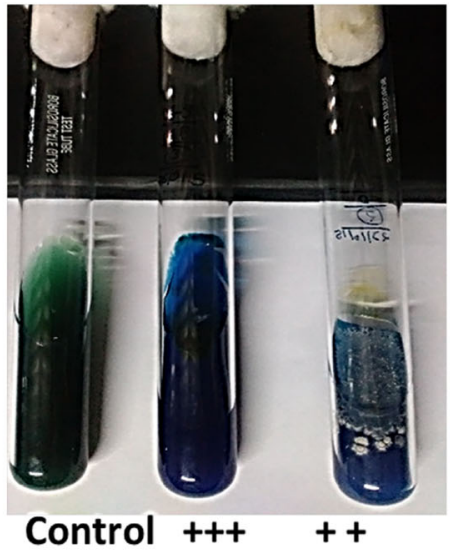

D Citrate test

Fig. 1 a-d Biochemical characterization of isolates bacterial strains

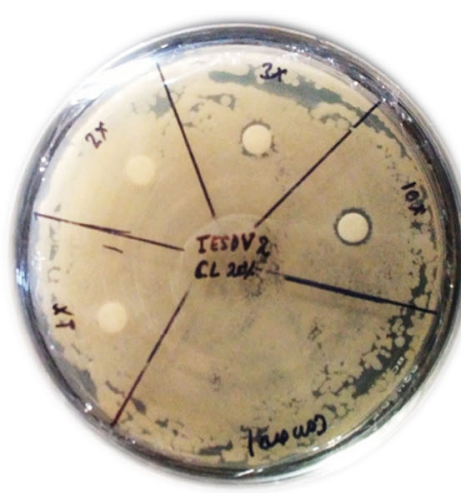

Less Tolerant

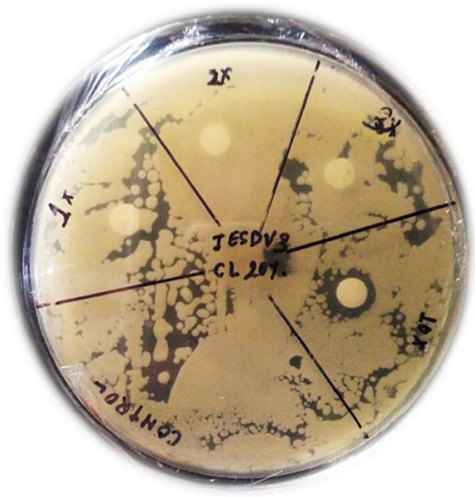

Moderate Tolerant

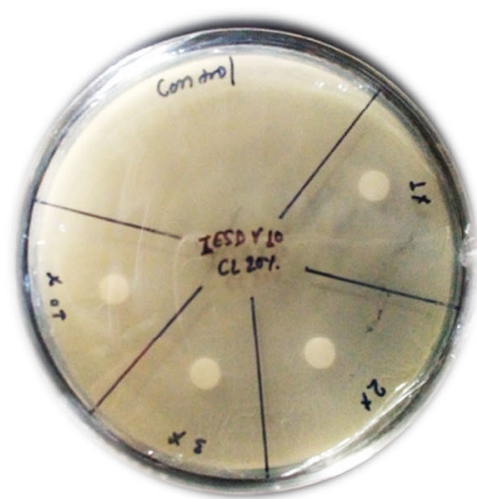

More Tolerant

Fig. 2 Microbial growth tolerance with chlorpyrifos pesticides

broth culture in the presence of tryptophan. Burkholderia cepacia IBSD-LKBI produced significant level of IAA at the rate of $58.4 \mu \mathrm{g} / \mathrm{ml}$ in culture filtrate (Devi et al. 2012). The conversion of tryptophan into IAA is the most important mechanism of soil microbes (Mohite 2013). Tryptophan-dependant IAA synthesis had been also determined in several soil microbes such as Pseudomonas fluorescens, Pseudomonas spp., Azotobacter spp., 
Table 5 Microbial growth tolerance ability test in the presence of different concentrations of chlorpyrifos pesticide

\begin{tabular}{|c|c|c|c|c|c|}
\hline \multirow[t]{2}{*}{ Strains } & \multicolumn{4}{|c|}{ Inhibition zone of chlorpyrifos $(2 \mathrm{ml} / \mathrm{l})$ after $48 \mathrm{~h}$} & \multirow[t]{2}{*}{ Tolerant } \\
\hline & $2 \mu \mathrm{l} / \mathrm{ml}$ & $4 \mu \mathrm{l} / \mathrm{ml}$ & $6 \mu \mathrm{l} / \mathrm{ml}$ & $20 \mu \mathrm{l} / \mathrm{ml}$ & \\
\hline IESDV1 & - & - & - & + & Mild \\
\hline IESDV2 & - & - & + & + & Less \\
\hline IESDV3 & - & - & - & + & Mild \\
\hline IESDV4 & - & + & + & + & Very less \\
\hline IESDV5 & - & - & - & - & More \\
\hline IESDV10 & - & - & - & - & More \\
\hline IESDV11 & - & - & - & + & Mild \\
\hline IESDV12 & - & - & - & - & More \\
\hline IESDV13 & - & - & - & - & More \\
\hline IESDV14 & - & - & + & + & Less \\
\hline IESDV23 & - & - & - & + & Mild \\
\hline IESDV26 & - & - & - & + & Mild \\
\hline IESDV27 & - & + & + & ++ & Very less \\
\hline IESDV28 & - & - & - & - & More \\
\hline
\end{tabular}

"+" sign mean positive test to give inhibition zone, "_" sign mean negative test to give no inhibition zone

Table 6 Plant growth-promoting properties of isolated microbial strains

\begin{tabular}{|c|c|c|c|c|}
\hline \multirow[t]{2}{*}{ Strains } & \multicolumn{2}{|c|}{ IAA $(\mu \mathrm{g} / \mathrm{ml}$ tryptophan) at 2 days } & \multirow{2}{*}{$\begin{array}{l}\text { Phosphate solubilization } \\
(\mu \mathrm{g} / \mathrm{ml}) \text { at } 3 \text { days }\end{array}$} & \multirow{2}{*}{$\begin{array}{l}\text { Ammonia } \\
\text { production }\end{array}$} \\
\hline & 150 & 300 & & \\
\hline IESDV1 & $15.64 \pm 0.45^{\mathrm{b}}$ & $17.98 \pm 2.01^{\mathrm{b}}$ & $25.26 \pm 3.01^{\mathrm{abc}}$ & ++ \\
\hline IESDV2 & $22.56 \pm 0.41^{\mathrm{gh}}$ & $23.19 \pm 1.53^{\mathrm{f}}$ & $30.80 \pm 1.32^{\mathrm{cd}}$ & + \\
\hline IESDV3 & $23.57 \pm 1.68^{\mathrm{hi}}$ & $26.61 \pm 0.60^{\mathrm{h}}$ & $33.44 \pm 1.05^{\mathrm{de}}$ & + \\
\hline IESDV4 & $20.03 \pm 0.24^{\mathrm{ef}}$ & $25.28 \pm 2.39^{\mathrm{g}}$ & $37.55 \pm 3.06^{\mathrm{ef}}$ & + \\
\hline IESDV5 & $21.02 \pm 0.34^{\mathrm{fg}}$ & $22.54 \pm 1.85^{\mathrm{ef}}$ & $21.36 \pm 2.73^{\mathrm{a}}$ & + \\
\hline IESDV10 & $25.61 \pm 0.65^{\mathrm{j}}$ & $22.30 \pm 1.61^{\mathrm{e}}$ & $23.30 \pm 1.87^{\mathrm{ab}}$ & ++ \\
\hline IESDV11 & $18.71 \pm 1.01^{\text {cde }}$ & $32.08 \pm 2.76^{j}$ & $33.17 \pm 2.43^{\mathrm{de}}$ & ++ \\
\hline IESDV12 & $30.58 \pm 0.35^{\mathrm{k}}$ & $34.91 \pm 1.89^{\mathrm{k}}$ & $39.83 \pm 2.12^{\mathrm{f}}$ & ++ \\
\hline IESDV13 & $17.37 \pm 1.05^{\mathrm{c}}$ & $17.68 \pm 2.20^{\mathrm{b}}$ & $25.82 \pm 2.64^{\mathrm{abc}}$ & ++ \\
\hline IESDV14 & $17.75 \pm 0.35^{\mathrm{cd}}$ & $20.96 \pm 1.22^{\mathrm{d}}$ & $27.82 \pm 1.87^{\mathrm{bcd}}$ & + \\
\hline IESDV23 & $13.03 \pm 2.50^{\mathrm{a}}$ & $13.74 \pm 1.91^{\mathrm{a}}$ & $25.94 \pm 1.54^{\mathrm{abc}}$ & + \\
\hline IESDV26 & $30.10 \pm 1.18^{\mathrm{k}}$ & $31.28 \pm 2.87^{\mathrm{i}}$ & $24.90 \pm 0.89^{\mathrm{abc}}$ & + \\
\hline IESDV27 & $24.80 \pm 0.52^{\mathrm{ij}}$ & $32.53 \pm 0.53^{j}$ & $22.16 \pm 1.06^{\mathrm{ab}}$ & + \\
\hline IESDV28 & $19.27 \pm 0.65^{\mathrm{def}}$ & $19.68 \pm 0.41^{\mathrm{c}}$ & $24.34 \pm 1.53^{\mathrm{ab}}$ & ++ \\
\hline
\end{tabular}

A values are the mean $\pm \mathrm{SD}$ (standard deviation), and mean values in each column with the same superscript (s) do not differ significantly, but different superscripts are showed significantly different between each treatments by Duncan post hoc test $(P \leq 0.05)$

“+” sign mean positive test, “-” sign mean negative test, IAA indole-3-acetic acid ( $\mu \mathrm{g} / \mathrm{ml})$ at 150 and $300 \mu \mathrm{g} / \mathrm{ml}$ tryptophan as precursor

Azospirillum spp., Phosphobacterium spp. and Glucanocetobacter spp. which were isolated from rice rhizosphere (Samuel and Muthukkaruppan 2011a, b).

Quantitative estimations of phosphate solubilization of isolated strains were detected on Pikovskaya broth media containing tricalcium phosphate under in vitro condition. The solubilization of $\mathrm{Ca}_{3}(\mathrm{PO} 4)_{2}$ in the liquid medium by isolating strains was accompanied by a significant drop in $\mathrm{pH}$ from an initial $\mathrm{pH}$ of $7.0 \pm 0.2$ after 3 days were recorded. The soluble-P concentration in the medium ranged from 21.36 to $39.83 \mu \mathrm{g} / \mathrm{ml}$ with variations among different isolates (Table 6; Fig. 3). The maximum P-solubilization was recorded by strain IESDV12, followed by strains IESDV4, IESDV11, IESDV3, IESDV2, IESDV28, IESDV14, IESDV1, IESDV23, IESDV13, IESDV26, IESDV28, IESDV10, IESDV27 and IESDV5. Phosphate solubilisation is a process to be done by microbes in soils to enhance availability of phosphate due to mechanisms of secretion of various organic acids as well alkaline and acidic phosphatase enzyme (Xiao et al. 2008; Singh et al. 


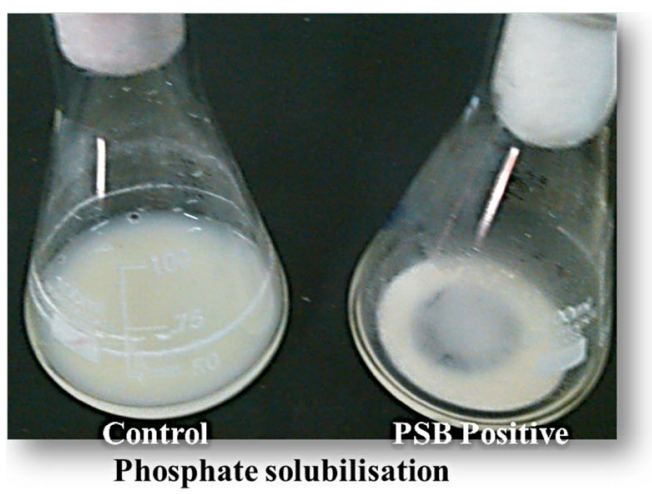

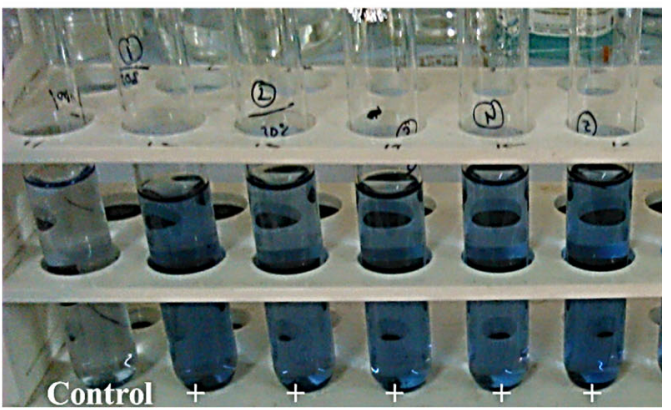

Quantification phosphate solubilisation

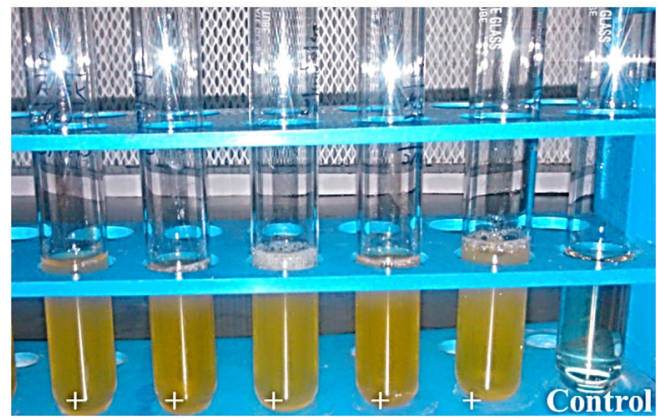

Ammonia production test

Fig. 3 Phosphate solubilization and ammonia production of isolated microbial strains

2010; Verma et al. 2010). The bacterial strains IESDV12 $(39.83 \mu \mathrm{g} / \mathrm{ml})$ and IESDV4 $(37.55 \mu \mathrm{g} / \mathrm{ml})$ were found more significant increase in phosphate solubilization followed by strains IESDV3 $(33.44 \mu \mathrm{g} / \mathrm{ml})$, IESDV11 $(33.17 \mu \mathrm{g} / \mathrm{ml})$, IESDV28 $(28.34 \mu \mathrm{g} / \mathrm{ml})$ and IESDV14 $(27.82 \mu \mathrm{g} / \mathrm{ml})$ as compared to other strains at 3-day incubation in broth culture (Table 6). Ahmad et al. (2008) reported several species of fluorescent pseudomonas such as P. fluorescens NJ10 and Bacillus sp. which is a good phosphate solubilizer. The phosphate solubilization ability in P. fluorescens, B. megaterium, Rhizobium sp. and A. chroococcum was reported by Verma et al. (2010). The inverse relationship observed between the $\mathrm{pH}$ changed and soluble phosphorus concentration in broth media indicates that organic acid production by these PGPM strains plays a significant role in acidification of the medium facilitating the phosphorus solubilization. The major source of phosphatase enzyme in the soils comes from microbial origin, and their activity increases substantially in the rhizosphere (Rodriguez and Fraga 1999). Ramani and Patel (2011) reported that Burkholderia cepacia has higher potential for the phosphate solubilization as compared to Bacillus spp.

The $\mathrm{NH}_{3}$ production is a special characteristic of plant growth-promoting bacteria because it directly helps in plant growth and yield. It is a direct mechanism of plant growth-promoting properties. All strains showed positive test for ammonia production. Strains IESDV1, IESDV10, IESDV11, IESDV12, IESDV13, IESDV14 and IESD28 expressed greater activities of ammonia production after 2 days (Fig. 3; Table 6). Ammonia is a primary source of nitrogen element for plant growth and yield so that ammonia positive strains are an important plant growthpromoting strain known as diazotrophic or nitrogen-fixing microbes. Verma et al. (2013) reported that the plant growth-promoting microbes have greater ability for ammonia production, which is isolated from rhizosphere soils. Recently, Beneduzi et al. (2008) advocated that the Bacillus and Paenibacillus have the ability of nitrogen fixation, synthesize IAA and solubilize phosphates which promote the growth of rice crops. In last, isolated microbial strains IESDV2, IESDV3, IESDV4, IESDV11, IESDV12, IESDV26, IESDV28 were recorded significant increase in the production of IAA, ammonia and phosphate solubilization as compared to others. Also isolated strains IESDV3, IESDV 11, IESDV12, IESDV 13 and IESDV28 showed tolerant on 6 and $20 \mu \mathrm{l} / \mathrm{ml}$ concentrations of chlorpyrifos pesticide. Overall, bacterial strains IESDV3, IESDV11, IESDV12 and IESDV28 have higher ability of plant growth-promoting properties and pesticide tolerant.

\section{Conclusion}

The isolated microbial strains IESDV4, IESDV2, IESDV3, IESDV11, IESDV12 and IESDV28 showed an increase in production of IAA, ammonia and phosphate solubilisation 
as compared to other strains. The isolated strains IESDV3 and IESDV 11 showed no inhibition zone at three times increase concentration of recommended dose $(2 \mu \mathrm{l} / \mathrm{ml})$ of chlorpyrifos, while the strains IESDV12, IESDV 13 and IESDV28 found a more tolerant on ten times increase concentration of recommended dose of chlorpyrifos pesticide. Overall conclusion, the isolated microbial strains IESDV3, IESDV11, IESDV12 and IESDV28 have found as more effective indigenous pesticide-tolerant plant growth-promoting microorganism as microbial consortia for enhancing sustainable vegetable production in eastern Uttar Pradesh. It is environmental friendly, economically viable and socially acceptable. It is also alternate to chemical fertilizer for enhancing agricultural production and soil fertility.

Acknowledgments Authors thankful to funding agency SERB (Science and Engineering Research Board), New Delhi, for providing fund for a project entitled "Studies of agriculturally important microorganism to develop effective microbial consortium for degradation of pesticide and insecticide in soil to enhance sustainable agriculture" for 2-year research work 2013-2015.

\section{References}

Abbasi MK, Sharif S, Kazmi M, Sultan T, Aslam M (2011) Isolation of plant growth promoting rhizobacteria from wheat rhizosphere and their effect on improving growth, yield and nutrient uptake of plants. Plant Biosyst 145:159-168

Ahmad F, Ahmad I, Khan MS (2008) Screening of free-living rhizospheric bacteria for their multiple plant growth promoting activities. Microbiol Res 168:173-181

Aktar MW, Sengupta D, Chowdhury A (2009) Impact of pesticides use in agriculture: their benefits and hazards. Interdiscip Toxicol 2(1): $1-12$

Ambethgar V (2009) Potential of entomopathogenic fungi in insecticide resistance management (IRM): a review. J Biopest 2(2):177-193

Aneja KR (2003) Experiments in microbiology, plant pathology and biotechnology, 4th edn. New Age International Publishers, Daryaganj, New Delhi

Armanpour S, Bing L (2015) Adsorption of herbicide Butachlor in cultivated soils of Golestan Province. Iran J Geosci Environ Prot 3:15-24

Bauer AW, Kirby WMM, Sherris JC, Turck M (1966) Antibiotic susceptibility testing by a standardized single disk method. Am J Clin Path 45(4):493-496

Beneduzi A, Peres D, Da Costa PB, Bodanese Zanettini MH, Passaglia LM (2008) Genetic and phenotypic diversity of plantgrowth-promoting bacilli isolated from wheat fields in southern Brazil. Res Microbiol 2008(159):244-250. doi:10.1016/j.resmic. 2008.03.003

Brick JM, Bostock RM, Silverstone SE (1991) Rapid in situ assay for indoleacetic acid production by bacteria immobilized on a nitrocellulose membrane. Appl Envir Micro 57(2):535-538

Cappuccino JC, Sherman N (1992) Microbiology: a laboratory manual, 3rd edn. Benjamin/cummings Pub. Co., New York, pp 125-179

Chopra SL, Kanwar JS (1982) Analytical agricultural chemistry. Kalyani Publishers, New Delhi, p 1621
Criollo H, Lagos T, Piarpuezan E, Pérez R (2011) The effect of three liquid bio-fertilizers in the production of lettuce (Lactucasativa L.) and cabbage (Brassica oleracea L. m. capitata). Agron Colomb 29(3):415-421

Devi SI, Somkuwar B, Potshangbam M, Talukdar NC (2012) Genetic characterization of Burkholderia cepacia strain from Northeast India: a potential bio-control agent. Adv Biosci Biotech 3:1179-1188. doi:10.4236/abb.2012.38144

Dunne C, Moënne-Loccoz Y, McCarthy J, Higgins P, Powell J, Dowling DN et al (1998) Combining proteolytic and phloroglucinol-producing bacteria for improved biocontrol of Pythiummediated damping-off of sugar beet. Pathol 47:299-307

Farenhorst M, Mouatcho JC, Kikankie CK, Brooke BD, Hunt RH, Thomas MB, Koekemoer LL, Knols BGJ, Coetzee M (2009) Fungal infection counters insecticide resistance in African malaria. Proc Natl Acad Sci USA 106(41):17443-17447

Glick BR (1995) The enhancement of plant growth by free-living bacteria. Can J Microbiol 41:109-117

Gupta AK, Samnotra RK (2004) Effects of biofertilizers and nitrogen on growth, quality and yield of cabbage (Brassica oleracea var. capitata) cv. Golden acre. Envir Ecol 22(3):551-553

Hafeez FY, Yasmin S, Ariani D, Mehboob-ur-Rahman Zafar Y, Malik KA (2006) Plant growth-promoting bacteria as biofertilizer. Agro Sust Dev 26:143-150

Hamada M, Matar A, Bashir A (2015) Carbaryl degradation by bacterial isolates from a soil ecosystem of the Gaza Strip. Braz J Microbiol 46(4):1087-1091

Jadhav SS, David M (2016) Biodegradation of flubendiamide by a newly isolated Chryseobacterium sp. strain SSJ1. 3 Biotech 6(1):31. doi:10.1007/s13205-015-0347-9

Kloepper JW, Beauchamp CJ (1992) A review of issues related to measuring of plant roots by bacteria. Can J Microb 38:1219-1232

Mallik MAB, Tesfai K (1983) Compatibility of Rhizobium japonicum with commercial pesticides in vitro. Bull Environ Contam Toxicol 31(4):432-437

Martensson AM (1992) Effects of agrochemicals and heavy metals on fast-growing rhizobia and their symbiosis with small-seeded legumes. Soil Biol Bioch 24(5):435-445

McCord JM, Keele BBJR, Fridovich I (1971) An enzyme-based theory of obligate anaerobiosis: the physiological function of superoxide dismutase. Proc Natl Acad Sci USA 68(5):1024-1027

Mohite B (2013) Isolation and characterization of indole acetic acid (IAA) producing bacteria from rhizospheric soil and its effect on plant growth. J Soil Sci Plant Nutr 13(3):638-649

Padmanabhan P, Padmanabhan S, De Rito C, Gray A, Gannon D, Snap JR, Tsai CS, Park W, Jeon C, Madsen EL (2003) Respiration of ${ }^{13} \mathrm{C}$-labelled substrates added to soil in the field and subsequent $16 \mathrm{~S}$ rRNA gene analysis of ${ }^{13} \mathrm{C}$ labeled soil DNA. Appl Environ Microbiol 69:1614-1622

Park JH, Feng Y, Ji P, Voice TC, Boyd SA (2003) Assessment of bioavailability of soil-sorbed atrazine. Appl Environ Microbiol 69:3288-3298

Paul A, Dubey R (2014) Isolation, characterization, production of biofertilizer and its effect on vegetable plants with and without carrier materials. Int J Curr Res 6(08):7986-7995

Quadt-Hallmann A, Kloepper JW (1996) Immunological detection and localization of the cotton endophyte Enterobacter asburiae JM 22 in different plant species. Can J Microbiol 42:1144-1154

Ramani V, Patel HH (2011) Phosphate solubilization by Bacillus sphaericus and Burkholderia cepacia in presence of pesticides. J Agric Technol 7(5):1331-1337

Rodriguez H, Fraga R (1999) Phosphate solubilizing bacteria and their role in plant growth promotion. Biotechnol Adv 17(4-5):319-339 
Samuel S, Muthukkaruppan SM (2011a) Characterization of plant growth promoting rhizobacteria and fungi associated with rice, mangrove and effluent contaminated soil. Curr Bot 2:22-25

Samuel S, Muthukkaruppan SM (2011b) Characterization of plant growth promoting rhizobacteria and fungi associated with rice, mangrove and effluent contaminated soil. Curr Bot 2(3):22-25

Setboonsarng S, Gilman J (2006) Alternative agriculture in Thailand and Japan. [internet] http://www.solutions-site.org/artman/pub lish/article_15.shtml

Shakoori AR, Makhdoom M, Haq RU (2000) Hexavalent chromium reduction by a dichromate-resistant gram-positive bacterium isolated from effluents of tanneries. Appl Microbiol Biot 53:348-351

Sharma RP, Lama TD, Yadava RB, Singh B, Pandey AK, Rai AB, Chaurasia SNS (2011) Nutrient management for Commercial vegetable production in India. Technical Bulletin No. 42, IIVR, Varanasi, pp 1-50

Sharma RP, Yadava RB, Lama TD, Bahadur A, Singh KP (2013) Status of secondary nutrients vis-à-vis soil site-characteristics of vegetable growing soils of Varanasi. Veg Sci 40(1):65-68

Siddique T, Okeke BC, Arshad M, JrWT Frankenberger (2003) Biodegradation kinetics of endosulfan by Fusarium vetricosum and a Pandoraea species. J Agric Food Chem 51:8015-8019

Singh SS, Mishra AK, Upadhyay RS (2010) Potentiality of Azolla as a suitable P-biofertilizer under salinity through acid phosphatase activity. Ecol Eng 36:1076-1082

Soltanpour PN and Workman SM (1979) Soil testing methods used at Colorado State University soil testing laboratory for the evaluation of fertility, salinity, sodicity and trace element toxicity. Colorado State University Experiment Station. Foot Coollins, Colorado Technology Bulletin, pp 14-22

Sparks DL, Page AL, Helmke PA, Loeppert RH, Soltanpour PN, Tabatabai MA, Sumner ME (1996) Methods of soil analysis. Part 3 chemical methods. Soil Science Society of America Inc., Madison
Verma JP, Yadav J, Tiwari KN, Lavakush Singh V (2010) Impact of plant growth promoting rhizobacteria on crop production. Int $\mathrm{J}$ Agri Res 5(11):954-983

Verma JP, Yadav J, Tiwari KN (2012) Enhancement of nodulation and yield of chickpea (Cicer arietinum L.) by co-inoculation of indigenous Mesorhizobium spp. and plant growth promoting rhizobacteria at eastern Uttar Pradesh. Commun Soil Plant Anal 43:605-621

Verma JP, Yadav J, Tiwari KN, Kumar A (2013) Effect of indigenous Mesorhizobium spp. and plant growth promoting rhizobacteria on yields and nutrients uptake of chickpea (Cicer arietinum L.) under sustainable agriculture. Ecol Eng 51:282-286

Verma JP, Jaiswal DK, Sagar R (2014) Pesticide Relevance and their microbial degradation: a-state-of-art. Rev Environ Sci Bio/Tech 13:429-466

Vessey JK (2003) Plant growth promoting rhizobacteria as biofertilizers. Plant Soil 255(2):571-586

Walkley A, Black IA (1934) An examination of the Degtjareff method for determining soil organic matter and a proposed modification of the chromic acid titration method. Soil Sci 37:29-38

Watanabe FS, Olsen SR (1965) Test of an ascorbic acid method for determining phosphorus in water and $\mathrm{NaHCO}_{3}$ extracts from soil. Soil Sci Sco Am Proc 29:677-678

Xiao C-Q, Chi R-A, Huang X-H, Zhang W-X, Qiu G-Z, Wang D-Z (2008) Optimization for rock phosphate solubilization by phosphate-solubilizing fungi isolated from phosphate mines. Ecol Eng 33:187-193

Yadav BD, Khandelwal RB, Sharma YK (2004) Use of biofertilizers (Azospirillum) in onion. Haryana J Hort Sci 33(3-4):281-283

Yadav J, Verma JP, Tiwari KN (2011) Plant growth promoting activities of fungi and their effect on chickpea plant growth. Asian J Biolog Sci 4(3):291-299 